Posh Talk 
This page intentionally left blank 


\section{Posh Talk}

\section{Language and Identity in Higher Education}

Siân Preece

Education Initiative Centre, University of Westminster, UK 
Softcover reprint of the hardcover 1st edition 2009 978-0-230-57398-7

All rights reserved. No reproduction, copy or transmission of this publication may be made without written permission.

No portion of this publication may be reproduced, copied or transmitted save with written permission or in accordance with the provisions of the Copyright, Designs and Patents Act 1988, or under the terms of any licence permitting limited copying issued by the Copyright Licensing Agency, Saffron House, 6-10 Kirby Street, London EC1N 8TS.

Any person who does any unauthorized act in relation to this publication may be liable to criminal prosecution and civil claims for damages.

The author has asserted her right to be identified as the author of this work in accordance with the Copyright, Designs and Patents Act 1988.

First published 2009 by PALGRAVE MACMILLAN

Palgrave Macmillan in the UK is an imprint of Macmillan Publishers Limited, registered in England, company number 785998, of Houndmills, Basingstoke, Hampshire RG216XS.

Palgrave Macmillan in the US is a division of St Martin's Press LLC, 175 Fifth Avenue, New York, NY 10010.

Palgrave Macmillan is the global academic imprint of the above companies and has companies and representatives throughout the world.

Palgrave ${ }^{\circledR}$ and Macmillan ${ }^{\circledR}$ are registered trademarks in the United States, the United Kingdom, Europe and other countries.

ISBN 978-1-349-36501-2

ISBN 978-0-230-24536-5 (eBook)

DOI $10.1057 / 9780230245365$

This book is printed on paper suitable for recycling and made from fully managed and sustained forest sources. Logging, pulping and manufacturing processes are expected to conform to the environmental regulations of the country of origin.

A catalogue record for this book is available from the British Library.

A catalog record for this book is available from the Library of Congress.

$\begin{array}{llllllllll}10 & 9 & 8 & 7 & 6 & 5 & 4 & 3 & 2 & 1\end{array}$

$\begin{array}{llllllllll}18 & 17 & 16 & 15 & 14 & 13 & 12 & 11 & 10 & 09\end{array}$ 


\section{For Cesario}

Born in Santas, Galicia in 1882, my grandfather, Cesario Conde, spent his childhood as a cowherd. At the dawn of the twentieth century, he left Spain in search of a better life. At the same age as many of the young people in this book, he worked his passage first to Liverpool, then Newfoundland and finally to Cardiff. On landing in Wales, he found work in Merthyr Tydfil, first as a navvy, building roads, and then stoking the furnaces in the local Iron Works, where he worked before and after the Great Depression of the 1930s. So he came to settle in South Wales, where he married my grandmother, Florence Dean, a baker's daughter, and raised two children, my uncle José and my mother, Gloria. Having received no formal education, or English language lessons, my grandfather was limited to the manual labouring jobs available at the time. During the Depression, along with many thousands of workers in South Wales, he was made redundant and was unemployed for eleven years before resuming work at the Iron Works. During these years, he supported the family with produce from his allotments and by picking coal, a life-threatening activity due to the precarious structure of the tunnels that the coal-pickers dug in the mountainside. His experiences gave him the hope that education could improve the prospects of his children and free them from poverty. This book is dedicated to his sacrifice and efforts to improve the lot of his family, to the millions of migrants around the world who seek a better life for themselves and their families, and to the power of education to realise some of their dreams. 
This page intentionally left blank 


\section{Contents}

List of Tables $\quad$ ix

Acknowledgements $\quad$ x

Transcription Conventions $\quad$ xi

Introduction $\quad \mathbf{1}$

$\begin{array}{ll}\text { Research ethos } & 6\end{array}$

$\begin{array}{lr}\text { The structure of the book } & 8\end{array}$

1 Widening Participation $\quad 11$

Introduction $\quad 11$

$\begin{array}{ll}\text { Expansion of tertiary education } & 11\end{array}$

$\begin{array}{ll}\text { Inequalities in access } & 13\end{array}$

$\begin{array}{ll}\text { Black and minority ethnic students } & 14\end{array}$

$\begin{array}{ll}\text { Linguistic diversity and widening participation } & 18\end{array}$

The local context: Millennium University 20

A snapshot of linguistic diversity at Millennium 22

Conclusion 25

2 Theorising and Analysing Identity 27

$\begin{array}{ll}\text { Introduction } & 27\end{array}$

Discourse $\quad 28$

Discoursing subjects $\quad 29$

$\begin{array}{ll}\text { Positioning } & 30\end{array}$

The theory/practice interface $\quad 33$

$\begin{array}{ll}\text { Spoken interactions } & 35\end{array}$

$\begin{array}{ll}\text { Communities of practice } & 37\end{array}$

$\begin{array}{ll}\text { Conclusion } & 38\end{array}$

3 Approaches to Academic Writing 40

Introduction $\quad 40$

Skills 41

Socialisation $\quad 44$

Literacies $\quad 49$

Conclusion $\quad 52$ 
4 Multilingual Masculinities in the Classroom 55

Introduction $\quad 55$

Presentations of self and fellow undergraduates 56

Representations of academic language and literacy practices $\quad 68$

Identifications with language $\quad 77$

Conclusion $\quad 82$

5 Multilingual Femininities in the Classroom 84

$\begin{array}{ll}\text { Introduction } & 84\end{array}$

Presentations of self and fellow undergraduates $\quad 85$

Representations of academic language and literacy practices $\quad 94$

Identifications with language $\quad 99$

$\begin{array}{ll}\text { Conclusion } & 107\end{array}$

6 Multilingual Masculinities in Lecturer/Student

$\begin{array}{ll}\text { Interactions } & 109\end{array}$

Introduction 109

Identification with language $\quad 110$

Identification with reading $\quad 123$

Conclusion 138

7 Multilingual Femininities in Lecturer/Student

Interactions $\quad 140$

Introduction 140

Identification with language $\quad 141$

Identification with reading $\quad 155$

$\begin{array}{ll}\text { Conclusion } & 168\end{array}$

8 Towards Inclusion $\quad 170$

Introduction $\quad 170$

Performances of gender 171

Orientation to the academic community 173

Towards inclusion $\quad 176$

Approaches to student writing 181

Attitudes to the perspectives and linguistic repertoires of multilingual learners $\quad 185$

$\begin{array}{ll}\text { Final thoughts } & 191\end{array}$

Notes 193

$\begin{array}{ll}\text { Bibliography } & 196\end{array}$

$\begin{array}{ll}\text { Index } & 209\end{array}$ 


\section{List of Tables}

1 Languages used at home and with peers among British-born males 110

2 Male students born overseas 117

3 Languages used at home and with peers among male students born overseas 118

4 Reading of choice at home for male students 123

5 Languages used at home and with peers among British-born females 141

6 Female students born overseas 144

7 Languages used at home and with peers among females

8 Reading of choice at home for female students 156 


\section{Acknowledgements}

There are many people who have supported me and made this book a reality through their cooperation, efforts and goodwill. My thanks go to the students on the academic writing programme for their willingness to participate in my study and their contributions throughout the research period. I am especially grateful to David Block, who supervised the research on which this book is based and made comments on the draft of this book. David's encouragement, insights and belief in me were a powerful motivation. I would also like to thank Peter Martin, Adrian Blackledge, Barry Stierer and Joan Swann for reading the draft book and making extremely helpful comments. During the production of this book, Peter died very unexpectedly. So many of us will miss his warm-hearted generosity and his passionate belief in multilingualism, which was such an inspiration.

Finally, words are inadequate to express my thanks to Phoebus for cheering me on and supporting me throughout this endeavour, and my family for their pleasure and pride in this achievement. 


\section{Transcription Conventions}

A slash / shows the end of a chunk of talk

A hyphen - illustrates an incomplete word or utterance

A question mark ? indicates question intonation

Pauses of less than one second are shown with a full stop inside brackets (.)

Pauses of one second and longer are timed to the nearest second and the number of seconds is put in brackets, (3)

Square brackets [on top of each other indicates the point where [speakers overlap

An equals sign at the end of one utterance $=$ and the start of the next speaker's utterance shows that there was no audible gap between speakers

Double brackets around a word or phrase shows that there is ((doubt about the transcription))

Double brackets around X's ((xxx)) shows that the speaker's utterance is inaudible or can't be made out

$<$ phrases or words in angled brackets $>$ is an additional comment by myself as the transcriber on what is happening at the time or the way in which something is said

Words or syllables in CAPital letters are spoken with extra emphasis

words or phrases enclosed by percentage symbols are spoken very \%quietly\%, almost like an aside

A dotted line marks the beginning of a stave

Reading the transcription between the dotted lines shows the interplay of the voices at that part of the conversation (like the instruments in a musical score)

Staves are used in places where it is not possible to represent overlap clearly using a format based on turn taking. 